\title{
THE EFFECT OF ACTINOMYCIN D ON THE ATTACHMENT REACTION OF IMPLANTATION IN MICE
}

\author{
ROSEMARY M. POLLARD, J. C. S. BREDL ANd C. A. FINN \\ Department of Physiology, The Royal Veterinary College, \\ Royal College Street, London $\mathcal{N W 1} 0 T U$
}

(Received 1st December 1972)

The antibiotic, actinomycin D, prevents the normal implantation of blastocysts (Psychoyos, 1967), and delays the development of the decidual cell reaction (Finn \& Martin, 1972), probably due to an effect on RNA synthesis. The first stage of implantation, i.e. increased vascular permeability', as shown by the extravasation of the dye Pontamine Sky Blue, takes place normally, and the growth and development of the blastocyst continues. The endometrial epithelium, however, does not degenerate and decidualization of the stromal cells fails to occur at the normal time, with the result that the blastocyst is surrounded by an intact epithelium (Finn \& Bredl, 1973).

The object of the present work was to investigate, with the electron microscope, the effect of the drug on the initial attachment of the trophoblast to the uterine epithelium in pregnant mice (the attachment reaction; Nilsson, 1966), and on the hormone-induced closure of the uterine lumen in ovariectomized mice. The administration of ovarian hormones to ovariectomized mice on a schedule which mimics the ovarian secretion during early pregnancy causes the uterine lumen to undergo a characteristic change in morphology culminating in very close contact of the epithelial surfaces from opposing sides (Pollard \& Finn, 1972). This closure reaction is dependent on oestrogen for full development and is akin to the attachment reaction of pregnancy.

In the first experiment, six pregnant mice were ovariectomized about $72 \mathrm{hr}$ after mating and given daily injections of $500 \mu \mathrm{g}$ progesterone. On the 2nd day of such treatment, $20 \mathrm{ng}$ oestradiol- $17 \beta$ were administered to precipitate implantation, and a single dose of $15 \mu \mathrm{g}$ actinomycin $\mathrm{D}$ was given $1 \frac{1}{2} \mathrm{hr}$ after the oestrogen injection.

In the second experiment, eleven ovariectomized cycling mice were primed with $100 \mathrm{ng}$ oestradiol for 3 days. After 2 days rest, they were given daily injections of $500 \mu \mathrm{g}$ progesterone for 4 days. On the 4th day of progesterone treatment, they were all given $20 \mathrm{ng}$ oestradiol-17 $\beta$, six of the mice being given $15 \mu \mathrm{g}$ actinomycin D $1 \frac{1}{2} \mathrm{hr}$ before the oestrogen, the remainder serving as controls.

In both experiments, the mice were killed 24 to $30 \mathrm{hr}$ after the oestrogen injection. The uteri were fixed for electron microscopy by perfusion as described previously (Pollard \& Finn, 1972) and thin sections were examined in the usual way. The pregnant mice were injected intravenously with Pontamine Sky Blue 
15 min before autopsy to delineate areas of the uterus containing implanting blastocysts (Psychoyos, 1961) and it was from these areas that sections were taken. As a check on the activity of the actinomycin D, a further experiment was carried out at the same time as the second experiment. Ten ovariectomized mice were prepared as before (five being given actinomycin D and five left as controls) but $2 \mathrm{hr}$ before autopsy, they were given $0.1 \mathrm{mg}$ colchicine. The uteri were fixed in Bouin's fluid and paraffin wax-embedded sections were prepared in the usual way for the demonstration of mitoses. The number of cells undergoing mitosis in the stroma was counted in a section taken at random from each uterus (Martin \& Finn, 1968).

Ultrastructural examination of the pieces of uterus containing implanting blastocysts revealed that all the animals showed a normal attachment reaction (Pl. 1, Fig. 1), demonstrating that the close contact between the trophoblast and uterine epithelium is not prevented by actinomycin $\mathrm{D}$. In the second experiment, five out of six uteri from actinomycin D-treated mice were in the second stage of closure (Pl. 1, Fig. 2) compared with four out of five from those not treated with actinomycin D. The mitotic counts for the two groups fixed in Bouin's fluid were as follows: actinomycin D-treated-1.6 $\pm 0 \cdot 40$; controls$40 \cdot 5 \pm 14 \cdot 9$.

Clearly, actinomycin D prevented the majority of the stromal cells going into mitosis but had no effect on the attachment reaction or uterine closure. As the drug is known to have a marked effect on the degeneration of the epithelial cells, which normally occurs a few hours after the attachment of the blastocyst (Finn \& Bredl, 1973), two explanations of the failure to affect the earlier surface reaction of the epithelium are possible. (1) The drug reaches the epithelium but the attachment reaction is controlled in a different manner to the subsequent epithelial degeneration, the latter being sensitive to actinomycin D and the former insensitive. (2) The drug does not reach the epithelium in sufficiently high concentration to affect the intracellular control mechanisms and the failure of epithelial degeneration is a reflection of the influence of the drug on the decidual reaction in the stroma, which may itself be dependent on stromal mitosis. In view of the fact that actinomycin $D$ inhibits programmed cell death in other circumstances-for example, the resorption of tadpole tails (Tata, 1971)-the first suggestion seems more likely. Presumably, the degeneration of the epithelial cells is programmed in the nucleus and requires the formation of new RNA, whereas the attachment reaction does not.

We wish to thank the Medical Research Council and the Wellcome Trust for financial support. Technical assistance from Mrs J. Downie and Miss G. Blair is also gratefully acknowledged.

\section{EXPLANATION OF PLATE 1}

Fig. 1. Implantation site from uterus of an ovariectomized pregnant mouse given oestrogen and progesterone $24 \mathrm{hr}$ previously to induce implantation, and treated with actinomycin $D$. The attachment reaction between the trophoblast $(T)$ and uterine epithelial surface $(E)$ is unaffected by the drug. $\times 30,000$.

FIg. 2. Uterine lumen showing second stage of closure induced in an ovariectomized mouse by oestrogen and progesterone treatment, unaffected by treatment with actinomycin D. $\times 40,000$. 
PLATE 1

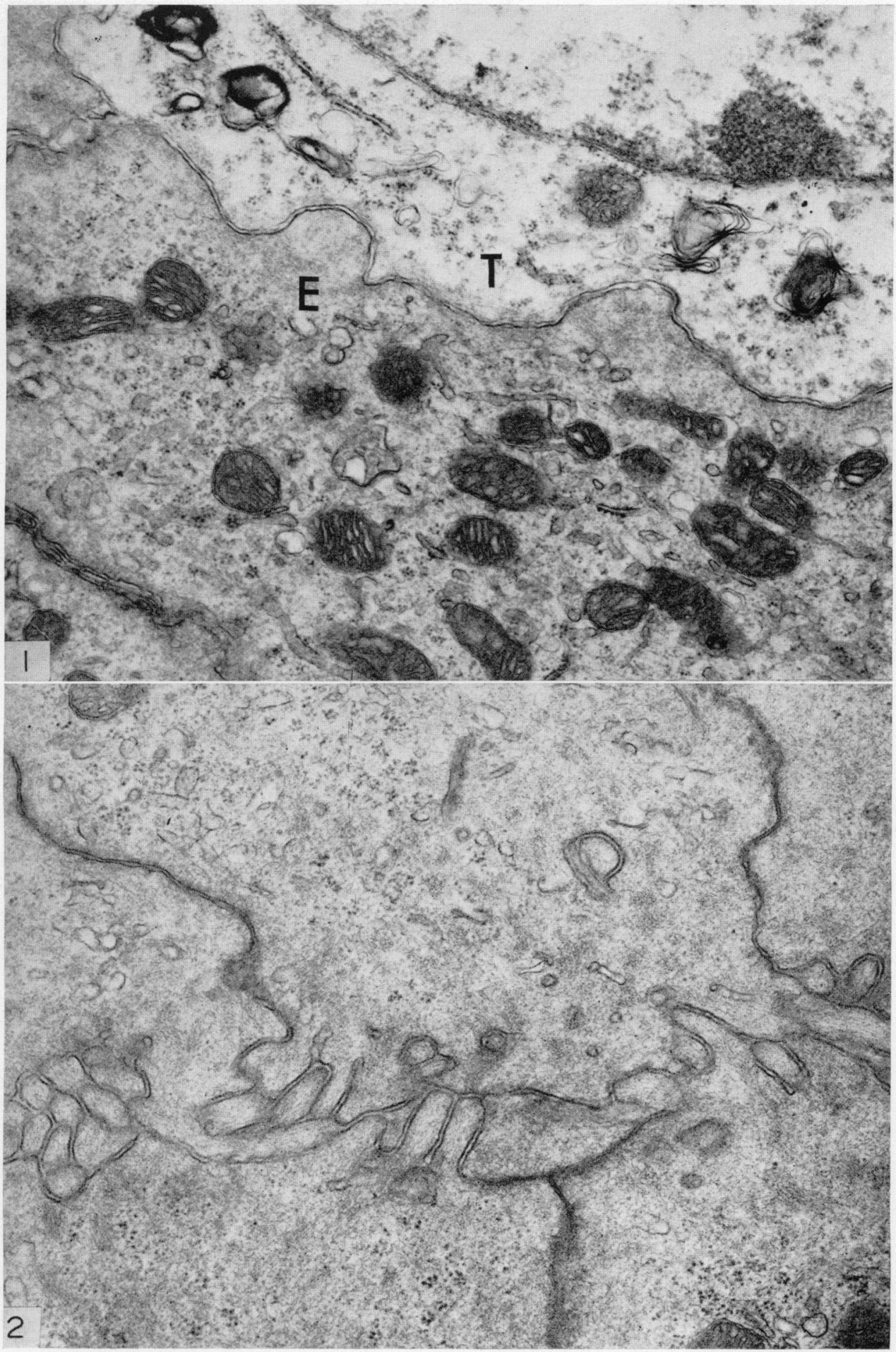




\section{REFERENCES}

FinN, C. A. \& BredL, J. C. S. (1973) Studies on the development of the implantation reaction in the mouse uterus: influence of actinomycin D. 7. Reprod. Fert. 34 (in press).

Fin, C. A. \& Martin, L. (1972) Temporary interruption of the morphogenesis of deciduomata in the mouse uterus by actinomycin D. J. Reprod. Fert. 31, 353.

Martin, L. \& FinN, C. A. (1968) Hormonal regulation of cell division in epithelial and connective tissues of the mouse uterus. 7. Endocr. 41, 363.

Nrcsson, O. (1966) Structural differentiation of luminal membrane in rat uterus during normal and experimental implantations. Z. Anat. EntwGesch. 125, 152.

Pollard, R. M. \& Finn, C. A. (1972) Ultrastructure of the uterine epithelium during the hormonal induction of sensitivity to a decidual stimulus in the mouse. $\mathcal{F}$. Endocr. 55, 293.

Psychoyos, A. (1961) Perméabilité capillaire et décidualization utérine. C.r. hebd. Séanc. Acad. Sci., Paris, 252, 1515.

Psychoyos, A. (1967) Mécanismes de la nidation. Archs Anat. microse. Morph. exp. 56, 616.

TATA, J. R. (1971) Protein synthesis during amphibian metamorphosis. In: Current Topics in Developmental Biology, Vol. 6, p. 79. Eds. A. A. Moscona and A. Monroy. Academic Press, New York and London. 